\title{
High open-circuit voltage solution-processed organic solar cells based on a star-shaped small molecule end-capped with a new rhodanine derivative
}

\author{
Yuanhang Zhou ${ }^{1,2}$, Weichao Chen ${ }^{1}$, Zhengkun Du ${ }^{1}$, Dangqiang Zhu ${ }^{1,2}$, Dan Ouyang ${ }^{1,2}$, \\ Liangliang $\operatorname{Han}^{1} \&$ Renqiang Yang ${ }^{1 *}$ \\ ${ }^{1}$ CAS Key Laboratory of Bio-based Materials, Qingdao Institute of Bioenergy and Bioprocess Technology, Chinese Academy of Sciences, \\ Qingdao 266101, China \\ ${ }^{2}$ University of Chinese Academy of Sciences, Beijing 100049, China
}

Received October 11, 2014; accepted November 11, 2014; published online January 4, 2015

\begin{abstract}
A new star-shaped small molecule named TCNR3TTPA, with a triphenylamine (TPA) unit as the central building block and 2-(1,1-dicyanomethylene)-3-octyl rhodanine (CNR) as the end-capped group, has been designed and synthesized. TCNR3TTPA showed a deep highest occupied molecular orbital (HOMO) energy level $(-5.60 \mathrm{eV})$ and broad absorption. The solution-processed bulk heterojunction (BHJ) solar cells based on TCNR3TTPA:PC ${ }_{61} \mathrm{BM}(1: 1, w / w)$ exhibited a high open-circuit voltage $\left(V_{\mathrm{oc}}\right)$ of $0.99 \mathrm{~V}$, a short-circuit current density $\left(J_{\mathrm{sc}}\right)$ of $5.76 \mathrm{~mA} / \mathrm{cm}^{2}$, and a power conversion efficiency (PCE) of $2.50 \%$ under the illumination of AM $1.5 \mathrm{G}, 100 \mathrm{~mW} / \mathrm{cm}^{2}$. The high $V_{\mathrm{oc}}$ is ascribed to the strong electron-with- drawing ability of the end-capped 2-(1,1-dicyanomethylene)-3-octyl rhodanine group. These results demonstrated that the $V_{\mathrm{oc}}$ of small-molecule organic solar cells could be increased by introducing a strong electron-withdrawing end-capped block, and that this is an effective strategy to design high-performance small molecules for organic solar cells.
\end{abstract}

organic solar cells, open-circuit voltage, triphenylamine, rhodanine derivative

\section{Introduction}

Organic solar cells (OSCs) have recently attracted significant attention due to their easy synthesis, potential to enable low-cost manufacture, and capability of fabricating flexible large-area devices [1]. Power conversion efficiencies (PCE) of exceeding $9 \%$ have been reached recently [2-9]. Currently, there are two types of electron donor materials: polymers and small molecules. Compared to their polymer counterparts, small molecules offer potential advantages in terms of uniform and defined molecular structures [10], generally higher open-circuit voltage $\left(V_{\text {oc }}\right)$ and hole mobility $[11,12]$, no batch-to-batch variation $[13,14]$, and high

*Corresponding author (email: yangrq@qibebt.ac.cn) purity. Thus, solution-processed small molecules OSCs have received more and more attention. Progress due to advances in the chemical structure of materials has mainly been achieved through the use of a donor-acceptor (D-A) approach that involves molecules based on alternating fragments of electron-rich and electron-poor groups [15]. This combination allows the molecular orbital to be tuned so as to enable intramolecular charge transfer (ICT) [16]. The intramolecular electronic communication between electron donor and accepter units is a key issue in a wide variety of areas including conducting materials, non-linear optics (NLO), molecular rectification, dyes, etc. [17]. The PCE of the OSCs is proportional to $V_{\mathrm{oc}}$, short-circuit current density $\left(J_{\mathrm{sc}}\right)$ and fill factor (FF) of the devices. As the important parameter, $V_{\text {oc }}$ is directly related to the gap between the highest occupied molecular orbital (HOMO) of the electron 
donor material and the lowest unoccupied molecular orbital (LUMO) of the fullerene. Therefore, $V_{\text {oc }}$ can be increased by down-shifting the HOMO of the donor materials or up-shifting the LUMO of the fullerene acceptor. In light of the above discussion, it is feasible to enhance the performance of OSCs when the molecule donors show low band gaps with broad and efficient optical absorption, matched energy levels, and high mobility [18]. Thus, one rational design strategy is to introduce strong electron-withdrawing units into the molecular backbone to tune the energy levels. Such units include 2-ethylhexyl cyanoacetate (CAO), malononitrile, and benzothiadiazole, all of which have showed good performance in solar cell devices.

We introduced a new strong electron-withdrawing unit 2-(1,1-dicyanomethylene)-3-octyl rhodanine (CNR) into the small molecule backbone. Rhodanine is a common dye unit that shows wide absorption spectra. Rhodanine derivatives have been used as acceptor moieties in a variety of pushpull organic compounds as second-order NLO [19] and analytical reagent [20]; recently, they have been used in small molecules OSCs [17,18,21-23]. For further improvement of the light absorption and $V_{\text {oc }}$, a dicyanomethylene unit was grafted into the rhodanine molecule. This new electronwithdrawing building block can not only produce wide absorption spectra but can also maintain excellent electron injection efficiency [21]. The double electron-withdrawing units of both rhodanine and dicyanomethylene can guarantee strong electron-accepting ability.

Triphenylamine (TPA) has also drawn much recent attention because of its good photovoltaic performance. TPA has a special propeller starburst molecular structure due to the $\mathrm{sp}^{3}$ hybrid orbital of the nitrogen atom [24]. As a result, amorphous materials with isotropic optical and chargetransporting properties could be expected when combining TPA with linear $\pi$-conjugated systems [25]. As electron donor groups, TPA and its derivatives have exhibited good performance in BHJ OSCs [26-35].

We also designed and synthesized a star-shaped, D-A type small molecule TCNR3TTPA with a TPA unit as a core D unit, oligothiophene as arms, and a CNR unit as endcapped groups. Prior research has shown that the oligothiophene backbone could offer a high mobility, and the side alkyl groups could give this compound good solubility [36]; thus, we expected to obtain a high-quality thin film by spin-coating. As we expected, TCNR3TTPA showed good thermal stability and a deep HOMO energy level $(-5.60 \mathrm{eV})$. The solution-processed BHJ OSCs based on TCNR3TTPA: $\mathrm{PC}_{61} \mathrm{BM}(1: 1)$ exhibited a PCE of $2.50 \%$ with a high $V_{\text {oc }}$ of $0.99 \mathrm{~V}$, under the illumination of AM $1.5 \mathrm{G}, 100 \mathrm{~mW} / \mathrm{cm}^{2}$. These results demonstrate that the end-capped block is an important factor in the determination of the $V_{\mathrm{oc}}$ of smallmolecule organic solar cells by tuning their energy levels, which is a prospective strategy to design new small molecules for organic solar cells.

\section{Experimental}

\subsection{Materials}

2-(1,1-Dicyanomethylene)-3-octyl rhodanine, 5"-bromo4',4"-dioctyl-[2,2':5',2"-terthiophene]-5-carbaldehyde, and tris-(4-(4,4,5,5-tetramethyl-1,3,2-dioxaborolan-2-yl)phenyl) amine were prepared according to the method reported in the literature $[23,28]$. Solvents were dried by standard procedure and distilled before use. All of the other chemicals were purchased from Aladdin (Bejing, China) and used without further purification.

\subsection{Measurements and instrumentations}

NMR spectra were carried out on a Bruker Advance III 600 spectrometer (German) using tetramethylsilane as an internal standard. High-resolution mass spectra were recorded on a Bruker Maxis UHR TOF spectrometer (Bruker, German) in APCI mode. The thermogravimetric analysis (TGA) was done on a SDT Q600 Simultaneous DSC-TGA instrument (TA, USA) under purified nitrogen gas flow with a $10{ }^{\circ} \mathrm{C} / \mathrm{min}$ heating rate. UV-Vis absorption spectra were performed on a Hitachi U-4100 spectrophotometer (Hitachi, Janpan). Cyclic voltammetry was measured on a CHI660D electrochemical workstation. Surface roughness and morphology of thin films were characterized by atomic force microscopy (AFM) on an Agilent 5400 (Agilent, USA). X-ray diffraction (XRD) spectra were recorded with a Bruker D8 Advance (Bruker, German).

\subsection{Device fabrication and characterization of OSCs}

Photovoltaic devices were fabricated by a simple spincoating process, with a general device structure of glass/ ITO/PEDOT:PSS/active layer/Ca/Al. The ITO-coated glass was ultrasonically cleaned with successive applications of acetone, methanol, and isopropyl alcohol. Oxygen plasma treatment was done for $10 \mathrm{~min}$ as the final step of substrate cleaning, to improve the contact angle just before film coating. Onto the ITO glass a layer of polyethylenedioxythiophene-polystyrene sulfonic acid (PEDOT:PSS) film with a thickness of $40 \mathrm{~nm}$ was spin-coated from its aqueous dispersion. PEDOT:PSS film was dried at $160{ }^{\circ} \mathrm{C}$ for 30 min in a oven. The solution of the small molecules and $\mathrm{PC}_{61} \mathrm{BM}$ in $\mathrm{CHCl}_{3}$ was prepared in a nitrogen-filled dry box and spin-coated on top of the ITO/PEDOT:PSS; the typical thickness of the active layer was $100 \mathrm{~nm}$. The concentration of the small molecule/ $\mathrm{PC}_{61} \mathrm{BM}$ blending solution used in this study was $15 \mathrm{mg} / \mathrm{mL}$. Subsequently, Ca $(10 \mathrm{~nm})$ and Al $(100 \mathrm{~nm})$ were thermally deposited at a vacuum of $2 \times 10^{-4}$ $\mathrm{Pa}$ on the top of active layer as a cathode. The current density-voltage $(J-V)$ characteristics of the devices were measured with a Keithley 2420 source measurement unit (Keithley, USA) under simulated $100 \mathrm{~mW} / \mathrm{cm}^{2}$ (AM $1.5 \mathrm{G}$ ) 
irradiation from a Newport solar simulator. Light intensity was calibrated with a standard silicon solar cell. The external quantum efficiencies (EQE) were analyzed using a certified Newport incident photon conversion efficiency measurement system (Newport, USA).

\subsection{Synthesis of the molecules}

The molecular structure and synthetic route of TCNR3TTPA are depicted in Scheme 1. The target molecule TCNR3TTPA was prepared by the Knoevenagel condensation and was confirmed by ${ }^{1} \mathrm{H}$ NMR spectra, ${ }^{13} \mathrm{C}$ NMR spectra, and other methods.

\subsubsection{Synthesis of TCHO3TTPA}

5"-Bromo-4',4"-dioctyl-[2,2':5',2"-terthiophene]-5-carbalde hyde (1 g, $1.73 \mathrm{mmol})$ and tris(4-(4,4,5,5-tetramethyl-1,3,2dioxaborolan-2-yl)phenyl)amine (0.3 g, $0.48 \mathrm{mmol}), \mathrm{Pd}$ $\left(\mathrm{PPh}_{3}\right)_{4}(0.15 \mathrm{~g}, 0.13 \mathrm{mmol})$, tetrabutylammonium bromide (0.03 g, $0.09 \mathrm{mmol})$, toluene $(20 \mathrm{~mL}), 2 \mathrm{~mol} / \mathrm{L} \mathrm{Na}_{2} \mathrm{CO}_{3}$ aqueous solution $(20 \mathrm{~mL})$ were mixed together in a $100-\mathrm{mL}$ round-bottom flask. The mixture was degassed and refluxed for $48 \mathrm{~h}$ and then cooled down to room temperature. Water was added and the mixture was extracted with dichloromethane. The organic layer was washed successively with brine and water, and then dried with $\mathrm{Na}_{2} \mathrm{SO}_{4}$. After the solvent was removed under reduced pressure, the crude product was purified by flash chromatography, using dichloromethane as eluent, to give TCHO3TTPA $(0.72 \mathrm{~g}, 86 \%) .{ }^{1} \mathrm{H}$ NMR (600 MHz, $\left.\mathrm{CDCl}_{3}\right): \delta 9.86(\mathrm{~s}, 3 \mathrm{H}), 7.67(\mathrm{~d}, J=3.9 \mathrm{~Hz}$, $3 \mathrm{H}), 7.40(\mathrm{~d}, J=8.5 \mathrm{~Hz}, 6 \mathrm{H}), 7.24(\mathrm{~s}, 3 \mathrm{H}), 7.22(\mathrm{~d}, J=3.6 \mathrm{~Hz}$, $6 \mathrm{H}), 7.20(\mathrm{~s}, 3 \mathrm{H}), 7.06(\mathrm{~s}, 3 \mathrm{H}), 2.84-2.75(\mathrm{~m}, 6 \mathrm{H})$, 2.75-2.64 (m, 6H), 1.73-1.62 (m, 12H), 1.47-1.19 (m, $60 \mathrm{H}), 0.89-0.86(\mathrm{~m}, 18 \mathrm{H}) .{ }^{13} \mathrm{C}$ NMR $\left(150 \mathrm{MHz}, \mathrm{CDCl}_{3}\right): \delta$ $182.43,147.16,146.54,141.40,140.45,139.00,138.36$, $137.45,133.22,132.99,132.88,130.05,129.17,128.92$, $128.90,124.18,123.86,31.89,30.97,30.50,29.54,29.53$, 29.43, 29.41, 29.27, 28.83, 22.68, 14.13. MS (ACPI) $\mathrm{m} / \mathrm{z}$ : Calcd. for $\mathrm{C}_{105} \mathrm{H}_{129} \mathrm{NO}_{3} \mathrm{~S}_{9}[\mathrm{M}]^{+}:$1740.7492. Found: 1740.7499 .

\subsubsection{Synthesis of TCNR3TTPA}

TCHO3TTPA (0.2 g, $0.12 \mathrm{mmol}), 2$-(1,1-dicyanomethylene)-3-octyl rhodanine (0.2 g, $0.72 \mathrm{mmol}), \mathrm{CH}_{3} \mathrm{COONH}_{4}$ (0.6 g, $7.78 \mathrm{mmol})$, and $\mathrm{CH}_{3} \mathrm{COOH}(30 \mathrm{~mL})$ were mixed

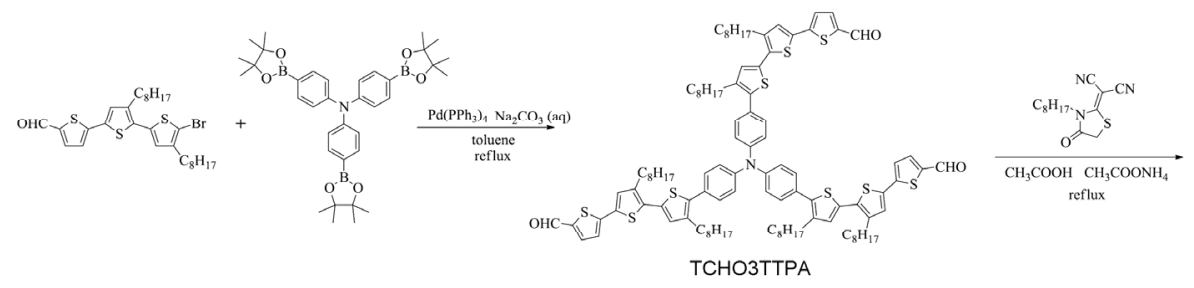

The thermal stability of TCNR3TTPA was investigated with thermogravimetric analysis (TGA) under a nitrogen

together in a 100-mL round-bottom flask. After degassing, the mixture was refluxed for $48 \mathrm{~h}$. After the reaction completed, water was added and the mixture was extracted with dichloromethane. The organic layer was washed successively with brine and water, and then dried with $\mathrm{Na}_{2} \mathrm{SO}_{4}$. After the solvent was removed under reduced pressure, the crude product was purified by flash chromatography, using dichloromethane as eluent, to give TCNR3TTPA (78.9 mg, 27\%). ${ }^{1} \mathrm{H}$ NMR (600 MHz, $\left.\mathrm{CDCl}_{3}\right): \delta 8.03(\mathrm{~s}, 3 \mathrm{H})$, 7.41-7.40 (m, 9H), 7.26-7.20 (m, 12H), $7.09(\mathrm{~s}, 3 \mathrm{H})$, 4.23-4.19 (m, 6H), 2.85-2.80 (m, 6H), 2.73-2.68 (m, 6H), $1.77-1.67(\mathrm{~m}, 18 \mathrm{H}), 1.42-1.26(\mathrm{~m}, 90 \mathrm{H}), 0.88-0.86(\mathrm{~m}$, 27H). ${ }^{13} \mathrm{C} \mathrm{NMR}\left(150 \mathrm{MHz}, \mathrm{CDCl}_{3}\right): \delta$ 166.03, 165.56, $146.67,146.56,140.73,139.08,138.49,136.87,134.96$, $133.53,132.86,132.55,130.04,129.34,128.98,128.89$, $128.75,124.74,124.20,113.43,113.15,112.32,55.69$, $45.38,31.90,31.71,30.99,30.58,29.66,29.58,29.56$, $29.44,29.42,29.31,29.28,29.09,29.05,28.85,28.83$, 25.97, 22.68, 22.61, 14.14, 14.08. Anal. calcd. for $\mathrm{C}_{147} \mathrm{H}_{180} \mathrm{~N}_{10} \mathrm{O}_{3} \mathrm{~S}_{12}$ : C, 70.07; H, 7.20; N, 5.56; S, 15.27. Found: C, 70.15; H, 7.29; N, 5.47; S, 15.36 .

\section{Results and discussion}

\subsection{Optical properties}

Figure 1 shows the UV-Vis absorption spectra of TCNR3TTPA in dilute $\mathrm{CHCl}_{3}$ solution and in the solid film on a quartz plate. The parameters are summarized in Table 1. The main absorption peak of the TCNR3TTPA thin film is red-shifted $17 \mathrm{~nm}$ relative to the peak in solution, which could be ascribed to the increased $\pi-\pi$ stacking interaction in the thin film. However, the small red-shift of this compound is believed to be related to its nonplanar structure. TPA shows special propeller starburst molecular structure caused by the center atom of nitrogen in TPA, which has lone-pair electrons [25]. The absorption edge of TCNR3TTPA film was located at $685 \mathrm{~nm}$, indicating an optical bandgap of $1.81 \mathrm{eV}$.

\subsection{Thermal properties}

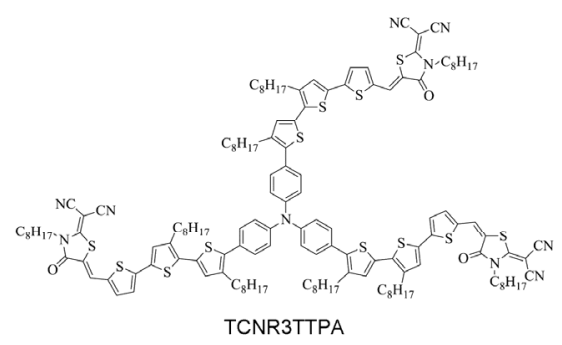

Scheme 1 Synthetic route of TCNR3TTPA. 
Table 1 Optical and electrochemical properties of TCNR3TTPA

\begin{tabular}{|c|c|c|c|c|c|c|c|c|}
\hline \multirow{2}{*}{$\begin{array}{l}\text { Solution } \\
\lambda_{\max }(\mathrm{nm})\end{array}$} & \multicolumn{2}{|c|}{ Film } & \multirow{2}{*}{$E_{\mathrm{g}}^{\text {opt }}(\mathrm{eV})$} & \multirow{2}{*}{$\varphi_{\mathrm{ox}}(\mathrm{V})$} & \multirow{2}{*}{$\varphi_{\text {red }}(\mathrm{V})$} & \multirow{2}{*}{$E_{\mathrm{g}}^{\text {chem }}(\mathrm{eV})$} & \multirow{2}{*}{ HOMO (eV) } & \multirow{2}{*}{ LUMO (eV) } \\
\hline & $\lambda_{\max }(\mathrm{nm})$ & $\lambda_{\text {edge }}(\mathrm{nm})$ & & & & & & \\
\hline 377,533 & 395,550 & 685 & 1.81 & 1.20 & -0.69 & 1.89 & -5.60 & -3.71 \\
\hline
\end{tabular}

atmosphere (Figure 2). The results reveal that the onset temperature with $5 \%$ weight-loss $\left(T_{\mathrm{d}}\right)$ of TCNR3TTPA is $400{ }^{\circ} \mathrm{C}$. Obviously, the thermal stability of TCNR3TTPA is adequate for its application in organic solar cells and other optoelectronic devices [37].

\subsection{Electrochemical properties}

Cyclic voltammetry (CV) has been widely employed to investigate the electrochemical behavior of compounds and to estimate their HOMO and LUMO energy levels [38,39]. The electrochemical property of TCNR3TTPA was explored by a $\mathrm{CV}$ method with film on a glassy carbon working electrode in $0.1 \mathrm{~mol} / \mathrm{L} n-\mathrm{Bu}_{4} \mathrm{NPF}_{6}$ acetonitrile solution at a potential scan rate of $100 \mathrm{mV} / \mathrm{s}$. The HOMO and LUMO energy levels of TCNR3TTPA can be calculated from their onset oxidation potential $\left(\varphi_{\mathrm{ox}}\right)$ and reduction po-

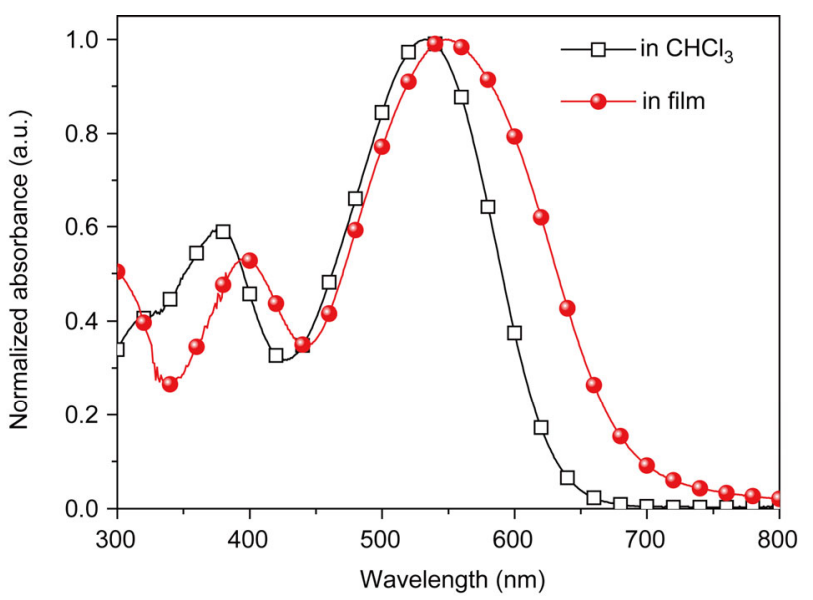

Figure 1 UV-Vis absorption spectra of TCNR3TTPA in $\mathrm{CHCl}_{3}$ solution and in thin film.

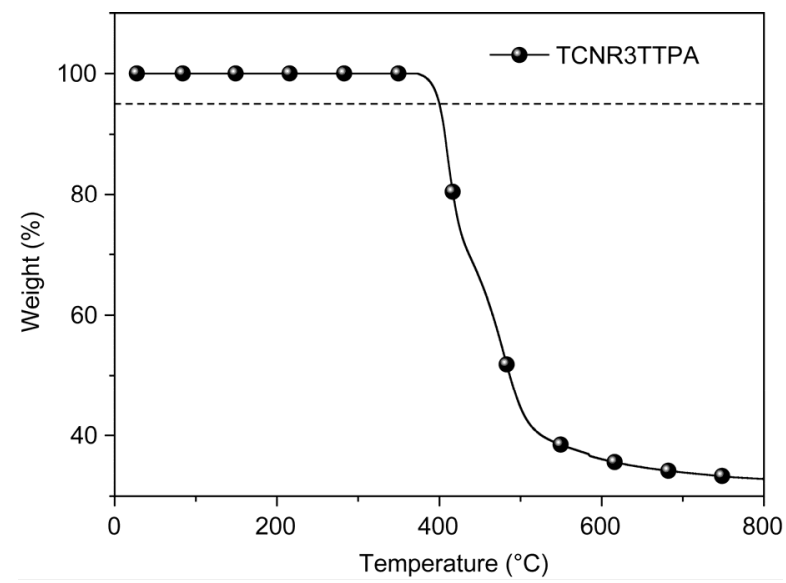

Figure 2 TGA curve of TCNR3TTPA. tential $\left(\varphi_{\text {red }}\right)$ according to the following equations: $E_{\mathrm{HOMO}}=$ $-\mathrm{e}\left(\varphi_{\mathrm{ox}}+4.4\right)(\mathrm{eV})$ and $E_{\mathrm{LUMO}}=-\mathrm{e}\left(\varphi_{\mathrm{red}}+4.4\right)(\mathrm{eV})$, where the unit of potential is $\mathrm{V}$ vs. $\mathrm{Ag} / \mathrm{AgCl}$. As shown in Figure 3, the $\varphi_{\text {ox }}$ of TCNR3TTPA is $1.20 \mathrm{~V}$ and $\varphi_{\text {red }}$ is $-0.69 \mathrm{~V}$ vs. $\mathrm{Ag} / \mathrm{AgCl}$. Thus the respective HOMO and LUMO energy levels as well as the electrochemical band gap of the TCNR3TTPA are $-5.60,-3.71$, and $1.89 \mathrm{eV}$. The electrochemical band gap $(1.89 \mathrm{eV})$ is slightly bigger than the optical band gap $(1.81 \mathrm{eV})$, probably because of the energy barrier between the molecular film and electrode for the oxidation and reduction in the $\mathrm{CV}$ measurement or because of the binding energy of excitons in the optical measurement $[3,40]$. The relatively low HOMO energy level of TCNR3TTPA is beneficial to a high $V_{\text {oc }}$ for the solar cells.

\subsection{Photovoltaic properties}

To explore potential application of TCNR3TTPA in BHJ OSCs, the devices with structure of ITO/PEDOT:PSS/TCNR3TTPA:PC ${ }_{61} \mathrm{BM} / \mathrm{Ca} / \mathrm{Al}$ were fabricated with TCNR3TT$\mathrm{PA}$ as the electron donor and $\mathrm{PC}_{61} \mathrm{BM}$ as the electron acceptor. The active layers were spin-coated from a $\mathrm{CHCl}_{3}$ blend solution of the two compounds, with no thermal annealing before deposition of the top electrode. Table 2 summarizes $V_{\mathrm{oc}}, J_{\mathrm{sc}}, \mathrm{FF}$, and PCE of the devices at different donor:acceptor weight ratios. The device at donor/acceptor weight ratio of 1:1 gave the best performance, with respective $V_{\mathrm{oc}}, J_{\mathrm{sc}}, \mathrm{FF}$, and PCE of $0.99 \mathrm{~V}, 5.76 \mathrm{~mA} / \mathrm{cm}^{2}, 0.44$, and $2.50 \%$. All of the devices exhibited fairly high $V_{\text {oc }}$, as we expected, and their values $(0.98-0.99 \mathrm{~V})$ were almost insensitive to the donor:acceptor weight ratio. The high $V_{\mathrm{oc}}$ is

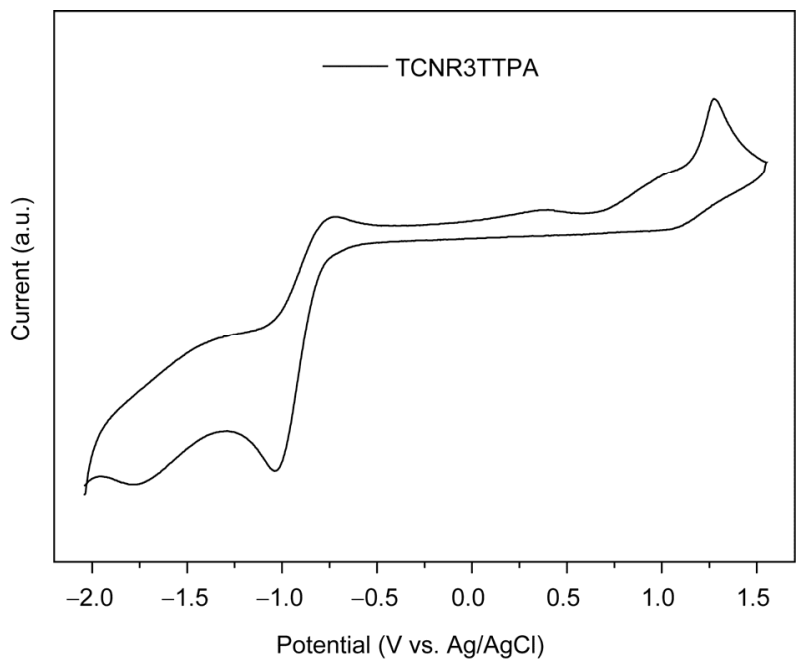

Figure 3 Cyclic voltammogram of TCNR3TTPA film on glassy carbon electrode in a $0.1 \mathrm{~mol} / \mathrm{L} n-\mathrm{Bu}_{4} \mathrm{NPF}_{6}$ acetonitrile solution at a scan rate of $100 \mathrm{mV} / \mathrm{s}$. 
ascribed to the deep HOMO energy level of TCNR3TTPA molecule (Figure 4).

Figure 5 shows the EQE spectra of device with the structure ITO/PEDOT:PSS/TCNR3TTPA:PC ${ }_{61} \mathrm{BM} \quad(1: 1, w / w) /$ $\mathrm{Ca} / \mathrm{Al}$. The EQE spectra of the blend film covers the visible region from 300 to $700 \mathrm{~nm}$ with a maximum of $38 \%$ at 420 $\mathrm{nm}$. The calculated photocurrent density from EQE spectra is $5.59 \mathrm{~mA} / \mathrm{cm}^{2}$, which shows only $3 \%$ deviation from the $J$ - $V$ measurement.

The preferable morphology of the active layer for highperformance OSCs is nanoscale phase separation, which enables a large interface area for exciton dissociation as well as a continuous percolating path for hole and electron

Table 2 The device data of OSCs based on TCNR3TTPA:PC ${ }_{61} \mathrm{BM}$

\begin{tabular}{|c|c|c|c|c|}
\hline TCNR3TTPA:PC ${ }_{61} \mathrm{BM}(w / w)$ & $V_{\mathrm{oc}}(\mathrm{V})$ & $J_{\mathrm{sc}}\left(\mathrm{mA} / \mathrm{cm}^{2}\right)$ & $\mathrm{FF}$ & PCE $(\%)$ \\
\hline $2: 1$ & 0.98 & 5.09 & 0.43 & 2.12 \\
\hline $1: 1$ & 0.99 & 5.76 & 0.44 & 2.50 \\
\hline $1: 2$ & 0.99 & 4.89 & 0.29 & 1.41 \\
\hline
\end{tabular}

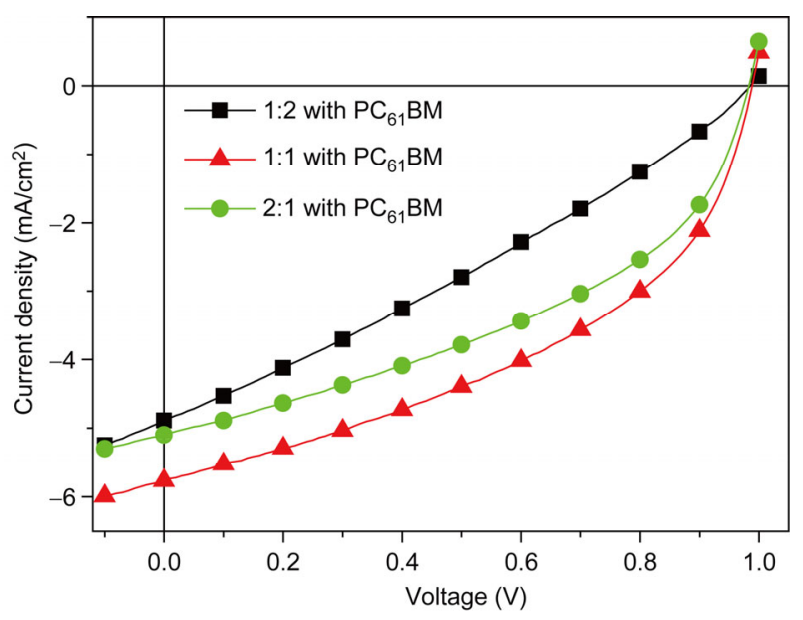

Figure $4 J-V$ curves of the OSCs based on TCNR3TTPA as donor and $\mathrm{PC}_{61} \mathrm{BM}$ as acceptor with different weight ratios $(1: 2-2: 1)$

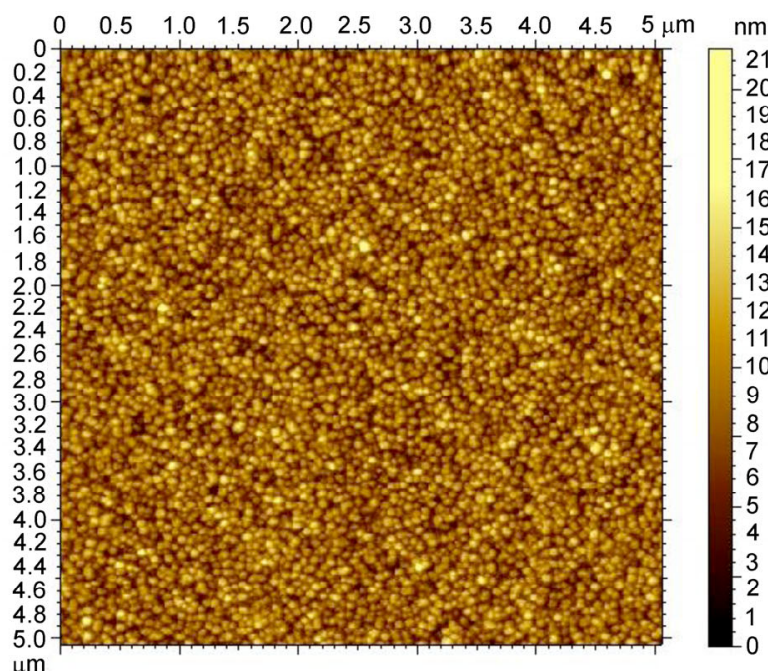

transport to the corresponding electrodes $[41,42]$. The morphology of the TCNR3TTPA:PC ${ }_{61} \mathrm{BM}(1: 1, w / w)$ blend film was explored by atomic force microscope (AFM, Figure 6). The film shows a relatively smooth surface with a root mean square (RMS) roughness of $2.45 \mathrm{~nm}$. Generally, the nanoscale interpenetrating network with a smooth surface is beneficial to enhance efficiency of the OSCs [43]. However, many crystalline grains and boundaries have the disadvantages of exciton dissociation and charge transport and therefore result in a relatively low $J_{\mathrm{sc}}$ and FF. The X-ray diffraction (XRD) analysis of the thin film shows no diffraction peak, which indicates that TCNR3TTPA has no obvious aggregation structure in the blend film [44].

\section{Conclusions}

We designed and synthesized a new star-shaped donor- acceptor molecule: TCNR3TTPA with TPA as a core, oligothiophene as arms, and CNR composed of rhodanine and

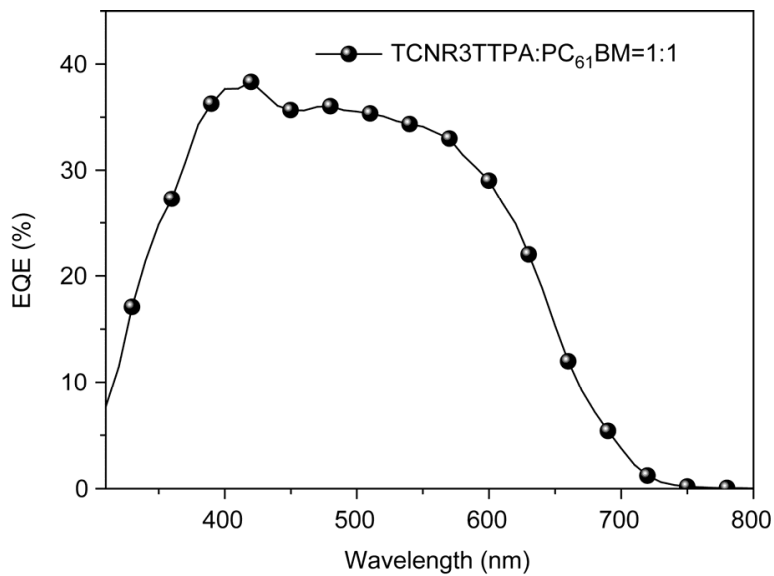

Figure 5 EQE spectra of the OSCs based on TCNR3TTPA:PC ${ }_{61} \mathrm{BM}(1: 1$, $w / w)$.

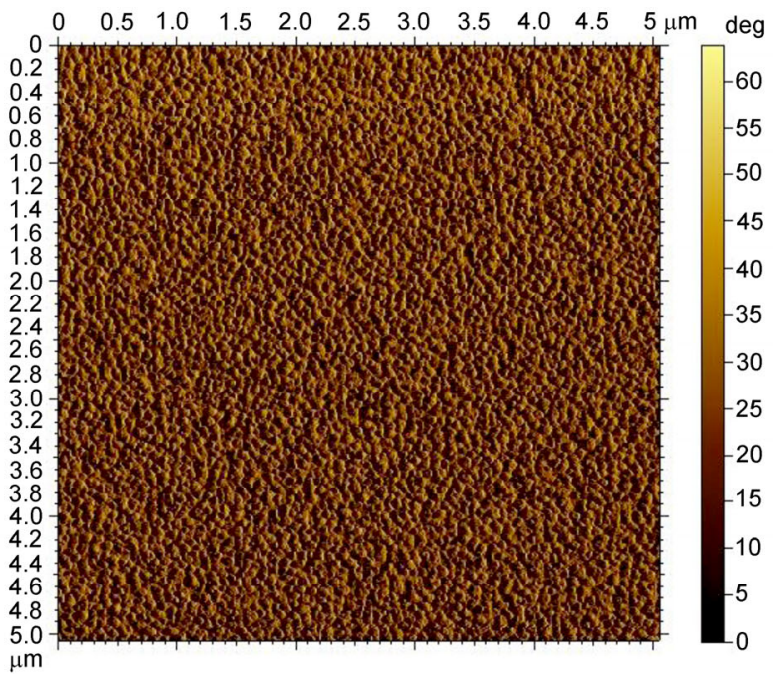

Figure 6 AFM topography (left) and phase (right) images of TCNR3TTPA:PC ${ }_{61} \mathrm{BM}(1: 1, w / w)$ blend film $(5 \mu \mathrm{m} \times 5 \mu \mathrm{m})$. 
dicyanomethylene units as end-capped groups. TCNR3TTPA is a broad bandgap (1.81 eV) molecule with a deep HOMO energy level of $-5.60 \mathrm{eV}$. The OSCs based on TCNR3TTPA:PC ${ }_{61} \mathrm{BM}(1: 1, w / w)$ showed a PCE of $2.50 \%$ with a high $V_{\text {oc }}$ of $0.99 \mathrm{~V}$. These results indicated that CNR is a strong electron-withdrawing block, as we expected, and that it caused a deep downshift in the HOMO of the compound. This is an effective method to increase the $V_{\text {oc }}$ of small-molecule solar cells by introducing a strong electronwithdrawing unit as the end-capped building block.

This work was supported by the National Natural Science Foundation of China (51173199, 51211140346, 61405209), the National Basic Research Program of China (2014CB643501, 2010DFA52310), the Shandong Provincial Natural Science Foundation (ZR2011BZ007), and the Qingdao Municipal Science and Technology Program (11-2-4-22-hz).

1 Yu G, Gao J, Hummelen JC, Wudl F, Heeger AJ. Polymer photovoltaic cells-Enhanced efficiencies via a network of internal donoracceptor heterojunctions. Science, 1995, 5243: 1789-1791

2 Xiao Z, Yuan Y, Yang B, VanDerslice J, Chen J, Dyck O, Duscher G, Huang J. Universal formation of compositionally graded bulk heterojunction for efficiency enhancement in organic photovoltaics. $A d v$ Mater, 2014, 19: 3068-3075

3 Zhang M, Gu Y, Guo X, Liu F, Zhang S, Huo L, Russell TP, Hou J. Efficient polymer solar cells based on benzothiadiazole and alkylphenyl substituted benzodithiophene with a power conversion efficiency over 8\%. Adv Mater, 2013, 35: 4944-4949

4 Osaka I, Kakara T, Takemura N, Koganezawa T, Takimiya K. Naphthodithiophene-naphthobisthiadiazole copolymers for solar cells: alkylation drives the polymer backbone flat and promotes efficiency. $J$ Am Chem Soc, 2013, 24: 8834-8837

5 Liu S, Zhang K, Lu J, Zhang J, Yip HL, Huang F, Cao Y. Highefficiency polymer solar cells via the incorporation of an aminofunctionalized conjugated metallopolymer as a cathode interlayer. $J$ Am Chem Soc, 2013, 41: 15326-15329

6 Hendriks KH, Heintges GH, Gevaerts VS, Wienk MM, Janssen RA. High-molecular-weight regular alternating diketopyrrolopyrrolebased terpolymers for efficient organic solar cells. Angew Chem Int Ed, 2013, 32: 8341-8344

7 Cabanetos C, El Labban A, Bartelt JA, Douglas JD, Mateker WR, Frechet JM, McGehee MD, Beaujuge PM. Linear side chains in benzo[1,2-b:4,5-b']dithiophene-thieno[3,4-c]pyrrole-4,6-dione polymers direct self-assembly and solar cell performance. J Am Chem Soc, 2013, 12: 4656-4659

8 Li X, Choy WC, Huo L, Xie F, Sha WE, Ding B, Guo X, Li Y, Hou J, You J, Yang Y. Dual plasmonic nanostructures for high performance inverted organic solar cells. Adv Mater, 2012, 22: 3046-3052

9 He Z, Zhong C, Huang X, Wong WY, Wu H, Chen L, Su S, Cao Y. Simultaneous enhancement of open-circuit voltage, short-circuit current density, and fill factor in polymer solar cells. Adv Mater, 2011, 40: 4636-4643

10 Kim FS, Guo X, Watson MD, Jenekhe SA. High-mobility ambipolar transistors and high-gain inverters from a donor-acceptor copolymer semiconductor. Adv Mater, 2010, 4: 478-482

11 Zhou JY, Wan XJ, Liu YS, Long GK, Wang F, Li Z, Zuo Y, Li CX, Chen YS. A planar small molecule with dithienosilole core for high efficiency solution-processed organic photovoltaic cells. Chem Mater, 2011, 1: 4666-4668

12 Welch GC, Perez LA, Hoven CV, Zhang Y, Dang XD, Sharenko A, Toney MF, Kramer EJ, Nguyen TQ, Bazan GC. A modular molecular framework for utility in small-molecule solution-processed organic photovoltaic devices. J Mater Chem, 2011, 34: 12700-12709

13 Demeter D, Rousseau T, Leriche P, Cauchy T, Po R, Roncali J. Ma- nipulation of the open-circuit voltage of organic solar cells by desymmetrization of the structure of acceptor-donor-acceptor molecules. Adv Funct Mater, 2011, 22: 4379-4387

14 Lin Y, Li Y, Zhan X. Small molecule semiconductors for highefficiency organic photovoltaics. Chem Soc Rev, 2012, 11: 42454272

15 Qin T, Zajaczkowski W, Pisula W, Baumgarten M, Chen M, Gao M, Wilson G, Easton CD, Mullen K, Watkins SE. Tailored donoracceptor polymers with an A-D1-A-D2 structure: controlling intermolecular interactions to enable enhanced polymer photovoltaic devices. J Am Chem Soc, 2014, 16: 6049-6055

16 Guo X, Baumgarten M, Müllen K. Designing $\pi$-conjugated polymers for organic electronics. Prog Polym Sci, 2013, 12: 1832-1908

17 Insuasty A, Ortiz A, Tigreros A, Solarte E, Insuasty B, Martin N. 2-(1,1-dicyanomethylene)rhodanine a novel, efficient electron acceptor. Dyes Pigm, 2011, 88: 385-390

18 He G, Li Z, Wan X, Liu Y, Zhou J, Long G, Zhang M, Chen Y. Impact of dye end groups on acceptor-donor-acceptor type molecules for solution-processed photovoltaic cells. J Mater Chem, 2012, 22: 9173-9180

19 Pushkara Rao V, Jen KYA, Caldwell JB. Rhodanine-methine as $\pi$ electron acceptor in second-order nonlinear optical chromophores. Tetrahedron Lett, 1994, 23: 3849-3852

20 Ray J, Panja N, Nandi PK, Martin JJ, Jones WE. Spectroscopic and ab initio study of an intramolecular charge transfer (ICT) rhodanine derivative. J Mol Struct, 2008, 1-3: 121-127

21 Zhou J, Zuo Y, Wan X, Long G, Zhang Q, Ni W, Liu Y, Li Z, He G, Li C, Kan B, Li M, Chen Y. Solution-processed and high-performance organic solar cells using small molecules with a benzodithiophene unit. J Am Chem Soc, 2013, 23: 8484-8487

22 Mao J, He N, Ning Z, Zhang Q, Guo F, Chen L, Wu W, Hua J, Tian H. Stable dyes containing double acceptors without cooh as anchors for highly efficient dye-sensitized solar cells. Angew Chem Int Ed, 2012, 39: 9873-9876

23 Higashijima S, Miura H, Fujita T, Kubota Y, Funabiki K, Yoshida T, Matsui M. Highly efficient new indoline dye having strong electron-withdrawing group for zinc oxide dye-sensitized solar cell. Tetrahedron, 2011, 34: 6289-6293

24 Lin Y, Zhang ZG, Bai H, Li Y, Zhan X. A star-shaped oligothiophene end-capped with alkyl cyanoacetate groups for solution-processed organic solar cells. Chem Commun, 2012, 77: 9655-9657

25 Ning Z, Tian H. Triarylamine: a promising core unit for efficient photovoltaic materials. Chem Commun, 2009, 37: 5483-5495

26 Min J, Luponosov YN, Gerl A, Polinskaya MS, Peregudova SM, Dmitryakov PV, Bakirov AV, Shcherbina MA, Chvalun SN, Grigorian S, Kaush-Busies N, Ponomarenko SA, Ameri T, Brabec CJ. Alkyl chain engineering of solution-processable star-shaped molecules for high-performance organic solar cells. Adv Energy Maters, 2014, 5: 1301324

27 Lin Y, Cheng P, Li Y, Zhan X. A 3D star-shaped non-fullerene acceptor for solution-processed organic solar cells with a high opencircuit voltage of 1.18V. Chem Commun, 2012, 39: 4773-4775

28 Wang G, Pu KY, Zhang XH, Li K, Wang L, Cai LP, Ding D, Lai YH, Liu B. Star-shaped glycosylated conjugated oligomer for two-photon fluorescence imaging of live cells. Chem Mater, 2011,20: 4428-4434

29 Shang H, Fan H, Liu Y, Hu W, Li Y, Zhan X. A solution-processable star-shaped molecule for high-performance organic solar cells. Adv Mater, 2011, 13: 1554-1557

30 Cravino A, Roquet $\mathrm{S}$, Alévêque $\mathrm{O}$, Leriche $\mathrm{P}$, Frère $\mathrm{P}$, Roncali J. Triphenylamine-oligothiophene conjugated systems as organic semiconductors for opto-electronics. Chem Mater, 2006, 10: 2584-2590

31 Zhu W, Zhang Y-M, Bao X, Xiao M, Tan H, tao q, Wang Y, Liu Y, Yang R. Significantly improved photovoltaic performance of the triangular-spiral TPA(DPP-PN $)_{3}$ by appending planar phenanthrene units into the molecular terminals. J Mater Chem A, 2015, 3: 886893

32 Zhang Y, Tan H, Xiao M, Bao X, Tao Q, Wang Y, Liu Y, Yang R, Zhu W. D-A-Ar-type small molecules with enlarged $\pi$-system of phenanthrene at terminal for high-performance solution processed 
organic solar cells. Org Electron, 2014, 6: 1173-1183

33 Lin Y, Wang Y, Wang J, Hou J, Li Y, Zhu D, Zhan X. A star-shaped perylene diimide electron acceptor for high-performance organic solar cells. Adv Mater, 2014, 30: 5137-5142

34 Lin Y, Zhang ZG, Li Y, Zhu D, Zhan X. One, two and three-branched triphenylamine-oligothiophene hybrids for solution-processed solar cells. J Mater Chem A, 2013, 16: 5128-5135

35 Lin Y, Wang H, Li Y, Zhu D, Zhan X. A star-shaped electron acceptor based on 5,5'-bibenzothiadiazole for solution processed solar cells. J Mater Chem A, 2013, 46: 14627-14632

36 Salleo A, Kline RJ, DeLongchamp DM, Chabinyc ML. Microstructural characterization and charge transport in thin films of conjugated polymers. Adv Mater, 2010, 34: 3812-3838

37 Wang K, Zhao Y, Tang W, Zhang ZG, Fu Q, Li Y. High open-circuit voltage polymer solar cells based on D-A copolymer of indacenodithiophene and fluorine-substituted benzotriazole. Org Electron, 2014, 3: $818-823$

38 Hou J, Tan Z, Yan Y, He Y, Yang C, Li Y. Synthesis and photovoltaic properties of two-dimensional conjugated polythiophenes with bi(thienylenevinylene) side chains. J Am Chem Soc, 2006, 14: 4911-
4916

39 Sun QJ, Wang HQ, Yang CH, Li YF. Synthesis and electroluminescence of novel copolymers containing crown ether spacers. $J$ Mater Chem, 2003, 4: 800-806

40 Bijleveld JC, Zoombelt AP, Mathijssen SG, Wienk MM, Turbiez M, de Leeuw DM, Janssen RA. Poly(diketopyrrolopyrrole-terthiophene) for ambipolar logic and photovoltaics. J Am Chem Soc, 2009, 46: 16616-16617

41 Zheng Q, Jung BJ, Sun J, Katz HE. Ladder-type oligo-p-phenylenecontaining copolymers with high open-circuit voltages and ambient photovoltaic activity. J Am Chem Soc, 2010, 15: 5394-5404

42 Brabec CJ, Sariciftci NS, Hummelen JC. Plastic solar cells. Adv Funct Mater, 2001, 1: 15-26

43 Savenije TJ, Kroeze JE, Yang XN, Loos J. The effect of thermal treatment on the morphology and charge carrier dynamics in a polythiophene-fullerene bulk heterojunction. Adv Funct Mater, 2005, 8: 1260-1266

44 Chang LL, Lademann HWA, Bonekamp JB, Meerholz K, Moule AJ. Effect of trace solvent on the morphology of P3HT:PCBM bulk heterojunction solar cells. Adv Funct Mater, 2011, 10: 1779-1787 